\title{
Brazilian spotted fever: description of a fatal clinical case in the State of Rio de Janeiro
}

\author{
Febre maculosa brasileira: descrição de um caso \\ fatal no Estado do Rio de Janeiro
}

Elba Regina Sampaio de Lemos ${ }^{1}$, Tatiana Rozental ${ }^{1}$ and Cid Leite Villela ${ }^{2}$

\begin{abstract}
We describe a case of Brazilian spotted fever in a previously healthy young woman who died with petechial rash associated to acute renal and respiratory insufficiency 12 days following fever, headache, myalgia, and diarrhea. Serologic test in a serum sample, using an immunofluorescence assay, revealed reactive lgM/lgG. Key-words: Spotted fever. Fatal case. Rio de Janeiro. Brazil.
\end{abstract}

Resumo Descreve-se um caso de febre maculosa brasileira numa paciente adulta, previamente saudável, que evoluiu para o óbito apresentando um quadro de exantema petequial associado à insuficiência respiratória e renal após 12 dias de doença caracterizada por febre, cefaléia, mialgia e diarréia. Teste de imunofluorescência indireta realizado em amostra de sangue foi reativo para $\operatorname{lgM}$ e $\lg G$ anti-Rickettsia rickettsii.

Palavras-chaves: Febre maculosa. Caso fatal. Rio de Janeiro. Brazil.

Brazilian spotted fever (BSF), which is caused by tick-borne Rickettsia ricketsii, is the most important and frequently reported rickettsial disease in Brazil|28911 14 . Amblyomma cajennense, distributed throughout Brazil, is the most important tick-vector 10121516 . As with Rocky Mountain spotted fever (RMSF) in North America, BSF has a rapid course, a great potential to cause death, and presents nonspecific clinical manifestations, mainly in the early stages, which resemble other infectious and noninfectious diseases ${ }^{12589}$. The initial manifestation is usually a flu-like syndrome characterized by a sudden onset of fever, malaise, myalgia, headache, associated with rash, which may be macular, maculopapular, petechiae, ecchymotic or purpuric, depending on the phase of the illness ${ }^{1} 235817$. In the majority of cases, complications and fatality are associated with misdiagnosis as well as delayed diagnosis and/or treatment $^{35814}$.

This report summarizes the clinical course of BSF in a 29 year-old woman residing in the Municipality of Nova Iguaçu, State of Rio de Janeiro that died after initial diagnosis of leptospirosis.

\section{CASE REPORT}

On July 17, 2001, a woman aged 29 years was referred to a physician with a 7-day history of fever, severe headache, myalgia and diarrhea. The patient was admitted to a public hospital with a diagnosis of leptospirosis and was immediately started on intravenous penicillin.

The epidemiologic investigation revealed that the patient lived in a semi-rural region and had contact with domestic animals and rodents.
In the clinical examination, the patient had an axillary temperature of $40^{\circ} \mathrm{C}$, a rash in the lower extremities, heart rate of 124 beats/minute and a blood pressure of $95 \times 60 \mathrm{mmHg}$, with respiratory and abdominal examination without abnormalities.

The hemoglobin was $10.7 \mathrm{~g} / \mathrm{dl}$, hematocrit was $28 \%$, white blood cell count was 5,410 leukocytes per cubic millimeter $(27 \%$ band forms, $50 \%$ neutrophils, $6 \%$ lymphocytes, $13 \%$ monocytes), and the platelet count

\footnotetext{
1. Departamento de Virologia do Instituto Oswaldo Cruz da Fundação Oswaldo Cruz, Rio de Janeiro, RJ, Brasil. 2. Hospital Geral de Nova Iguaçu, Rio de Janeiro, Brasil.

Address to: Dra Elba R.S. Lemos. Dept ${ }^{\circ}$ de Virologia/IOC/FIOCRUZ. Av. Brasil 4365, Manguinhos, 21045-900 Rio de Janeiro, RJ, Brazil.

Fax: $55212270-6397$

e-mail:elemos@ioc.fiocruz.br

Recebido para publicação em 11/03/2002
} 
was 20,600 per cubic millimeter. The serum glucose was $119 \mathrm{mg} \%$, creatinine $5.6 \mathrm{mg} \%$, aspartate aminotransferase (AST) 289U/l, alanine aminotransferase (ALT) 426U/I and elevation of direct bilirubin $3.3 \mathrm{mg} \%$. Serologic test for leptospirosis (macroagglutination) was positive. The chest X-ray was normal.

Shortly after admission, the symptoms worsened, the patient developed disorientation, dehydration, seizures and respiratory distress, following which she was transferred to the intensive care unit.

On July 20, the patient, under mechanical ventilation and hemodialysis, developed a diffuse maculopapular rash with petechiae, when therapy with intravenous chloramphenicol for possible BSF was initiated. Laboratory findings, showed a white blood cell count of $18,900(19 \%$ band forms, $65 \%$ neutrophils, $10 \%$ lymphocytes, $4 \%$ monocytes). Analysis of the cerebrospinal fluid was normal. Serological tests for leptospirosis (microagglutination), dengue (enzyme-linked immunosorbent assay /MACELISA), Ehrlichia (indirect immunofluorescence assay - IFA), viral hepatitis (ELISA) were all negative.

On July 23 , the patient subsequently developed upper gastrointestinal bleeding and died. Serologic test for BSF, using an IFA, in serum samples collected on the $20^{\text {th }}$ and $23^{\text {rd }}$ July, revealed negative $\lg \mathrm{M} / \lg \mathrm{G}$ and reactive $\lg \mathrm{M}(1: 8) /$ $\lg G(1: 64)$, respectively.

\section{DISCUSSION}

BSF had been identified in Brazil since the late 1890s, but the first cases were reported in $1931^{1}$. Although BSF is not a nationally notifiable disease, the majority of confirmed cases are reported in the states of the Southeastern region (Espírito Santo, Minas Gerais, Rio de Janeiro and São Paulo). Since the 1970's, several confirmed and suspected cases have been reported in the State of Rio de Janeiro, including the region of Nova Iguaçu, where this fatal case occurred2678910111214.

The clinical characteristics of BSF seen in this case did not differ from those described in other parts of Brazil or in other countries within the American continent. Since only $3-18 \%$ of the patients present with rash, fever, headache and a history of tick bite, its diagnosis can be difficult ${ }^{12814}$, especially during the first days of illness, when the clinical manifestations can suggest leptospirosis, dengue, viral hepatitis, salmonellosis or encephalitis. With development of rash, meningococcemia, measles, rubella, enteroviral infection, infectious mononucleosis, staphylococcal septicemia, gram-negative sepsis, drug eruption, systemic lupus erythematosus, among other diseases, may be confused with BSF 35891314 .

Laboratory abnormalities such as thrombocytopenia, anemia, hyponatremia, pre-renal azotemia, as well as nonspecific elevations of enzymes such as alkaline phosphatase, and aspartate transaminase can help to recognize BSF2 38101114 .

Complications, notably renal failure, seizure, secondary infections, coma and consequent high mortality rate are associated with misdiagnosis, delayed diagnosis and/or treatment. Several studies show that late initiation of specific antirickettsial therapy (after five days of illness) is associated with substantially greater risk for a fatal outcome ${ }^{35}$. Thus, the treatment must be started on an empiric basis, before results are available from the serologic specimens, because the changes in the diagnostic titers usually occur suddenly and only after 7-10 days of illness (IFA) ${ }^{17}$.
$R$. rickettsii is susceptible to antimicrobial agents, such as chloramphenicol, and tetracycline ${ }^{45}$. Although ciprofloxacin and ofloxacin also present in vitro activity against $R$. rickettsii, data are insufficient for use of these drugs in the treatment of BSF. Most antibiotics, such as penicillin, cephalosporin, aminoglycosides, erythromycin, and trimethoprim-sulfamethoxazole are ineffective for rickettsia ${ }^{1819}$.

Prevention of BSF can be acheived by avoiding exposure to ticks, mainly during June-October; by inspecting the body, head and clothes for ticks and removing the attached ticks after time spent in wooded or grassy areas or after contact with animals.

As BSF continues to be a potentially lethal threat, any individual with fever, malaise, and other infectious manifestations who has been in a BSF-endemic area or has been bitten by ticks and/or had contact with animals, must receive empiric antimicrobial therapy without waiting for development of the rash or serologic result, mainly during the period between June and October. Thus, a prompt anti-rickettsia therapy within the first days of onset of illness should contribute to reduce the high mortality rates that have been observed on reported spotted fever cases in Brazil.

Finally, during analysis of this fatal case we were informed that since January, 2001, in the Grama/Miguel Couto (region of the municipality of Nova Iguaçu), a further nine fatal cases have occurred without confirmed diagnosis. Could these be due to BSF? Preliminary analysis of the evaluation, by using IFA, of the serum samples stored in the Brazilian National Reference Center for Leptospirosis/FIOCRUZ from a total of 234 inhabitants from this region showed two samples reactive with low antibody titers to $R$. rickettsii. More information will be reported after studies that we will develop in this region.

\section{ACKNOWLEDGEMENTS}

The authors wish to thank Dr. Martha Maria Pereira for providing serum samples from Brazilian National Reference Center for Leptospirosis (FIOCRUZ) and Dr. James Olson (CDC) for providing the antigen used in this study. 


\section{REFERENCES}

1. Dias E, Martins AV. Spotted fever in Brazil. (1939). A summary. American Journal of Tropical Medicine 19: 103-108, 1931.

2. Gonçalves AJR, Lopes PF, Melo JC, Pereira AA, Pinto AM, Lazera MS, Souza MLS, Teixeira CRU, Oliveira JC, Duarte F. Rickettsioses - a propósito de quatro casos diagnosticados no Rio de Janeiro de febre maculosa brasileira. Folha Médica (BR) 82: 127-134, 1981.

3. Helmick CG, Bernard KW, D'Angelo LJ. Rocky Mountain spotted fever: clinical, laboratory, and epidemiological features of 262 cases. Journal Infectious Diseases 150: 480-488, 1984.

4. Holman RC, Paddock CD, Curns AT, Krebs JW, McQuiston JH, Childs JE. Analysis of risk factors for fatal rocky Mountain spotted fever: evidence for superiority of tetracyclines for therapy. Journal Infectious Diseases 184: 1437-1444, 2001.

5. Kirkland KB, Wilkinson WE, Sexton DJ. Therapeutic delay and mortality in cases of rocky Mountain spotted fever. Clinic Infectious Diseases 20: 1118-1121, 1995.

6. Lemos ERS. Aspectos epidemiológicos da riquetsiose do grupo da febre maculosa em uma área endêmica do Estado de Minas Gerais, Brasil. Tese de Mestrado, Instituto Oswaldo Cruz, Rio de Janeiro, 1991.

7. Lemos ERS. Febre maculosa brasileira em uma área endêmica no município de Pedreira, São Paulo. Tese de Doutorado, Instituto Oswaldo Cruz, Fundação Oswaldo Cruz, Rio de Janeiro, 1996.

8. Lemos ERS, Alvarenga FBA, Cintra ML, Ramos MC, Paddock CD, Ferebee TL, Zaki SR, Ferreira FCC, Ravagnani RC, Machado RD, Guimarães MAAM, Coura JR. Spotted fever in Brazil: a seroepidemiological study and description of clinical cases in an endemic area in the state of São Paulo. The American Journal Tropical Medicine and Hygiene 65: 329-334, 2001.

9. Lemos ERS, Nogueira RMR, Siqueira MAMT, Rozental T, Miagostovick MP, Cruz AS, Silva ED, Pereira MM. Measles, rubella, spotted fever group rickettsiosis and leptospirosis in patients with clinical diagnosis of dengue in Rio de Janeiro, Brazil.
Preliminary results. In: Resumos do XXV Congresso da Sociedade Brasileira de Medicina Tropical, Guarapari, p, 1999.

10. Magalhães $\mathrm{O}$. Contribuição ao conhecimento das doenças do grupo tifo exantemático. Monografia do Instituto Oswaldo Cruz, 1952.

11. Melles HHB, Colombo S, Silva MV. Febre maculosa: isolamento de rickettsia em amostra de biópsia de pele. Revista do Instituto de Medicina Tropical de São Paulo 34: 37-41, 1992.

12. Monteiro JL. Estudos sobre o typho exanthemático de São Paulo (1를 $2^{\mathrm{a}}$ parte). Memórias do Instituto Butantan 6:1-136, 1931.

13. Salgo MP, Telzec EE, Currie B, Perlman DC, Litman N, Levi M, Nathenson G, Benach JL, Alhafidh R, Casey J. A focus of Rocky Mountain spotted fever with New York City. New England Journal of Medicine 318: 1345-1348, 1988.

14. Sexton DJ, Muniz M, Corey GR, Breitschwerdt EB, Hegarty BC, Dumler S, Walker DH, Peçanha PM, Diezte R. Brazilian spotted fever in Espírito Santo, Brazil: Description of a focus of infection in a new endemic region. The American Journal of Tropical Medicine and Hygiene 49: 222-226, 1993.

15. Travassos J. Studies on rickettsial diseases in Brazil. In: Whitlock C (ed) Proceedings of the $4^{\text {th }}$ International Congress of Tropical Medicine and Malaria. US Government Printing Office, Washington, DC p. 414-421, 1948.

16. Travassos J, Dias E. Febre maculosa. Identidade imunológica dos vírus de Minas Gerais, São Paulo e das Montanhas Rochosas. Memórias do Instituto Oswaldo Cruz 34: 149-179, 1939.

17. Walker DH. Rocky Mountain spotted fever: a disease in need of microbiological concern. Clinical Microbiology Review 2: 227- 240, 1989.

18. Wisseman CL, Waddell A. In vitro sensitivity of Rickettsia rickettsi to doxycycline. Journal Infectious Diseases 145: 584, 1982.

19. Wisseman CL Jr, Ordonez SV. Actions of antibiotics on Rickettsia rickettsii. Journal Infectious Diseases 153: 626-628, 1986. 